\title{
STUDY OF FORCED MIGRATION AS A MAJOR REASON FOR INTERNAL AND EXTERNAL MIGRATION IN UKRAINE
}

\author{
Natalia Tilikina \\ Deputy Director on Scientific Work \\ State Institute for Family and Youth Policy \\ 18 Issakyana str., Kyiv, Ukraine, 01135 \\ tilikina_natalia@ukr.net
}

\begin{abstract}
The article analyzes current internal and external migration in Ukraine. There was found out that forced migration flows caused drastic changes in directions of internal migration and its structure. External migration of Ukrainian population has undergone significant changes. As to internally displaced people, they experience low level of well-being, job and housing security. It also discovers qualitative and quantitative characteristics of forced and labor migration, and makes suggestions concerning intensification of state efforts in the sphere of migration policy in Ukraine.

Keyword: forced migration, internal migration, external migration, labor migration, internally displaced persons, net migration, illegal migration.
\end{abstract}

\section{Introduction}

A contemporary state of society development in Ukraine is characterized by quite a high level of internal and external migration processes. The actions on the East of Ukraine caused a new wave of internal and external population movement - a lot of forced migrants found themselves in a difficult situation. These migrants had to move to a new place of residence, look for a job; moreover, they experienced socioeconomic troubles and did not have place where to live in, etc. Moreover migration attitudes increase among other population layers and change migration directions as well. That is why it is necessary for the state to revise its migration policy and find new effective mechanisms for migration processes regulation.

\section{Review of main sources of research and publications}

The general characteristics of Ukrainian population migration flows in general and individual groups in particular can be found in the statistical compilations of the State Statistics Service of Ukraine [1]. Internal and external migration tendencies and labor migration flows are studied in the analytical reports of the central executive agencies [2]. Works of Ukrainian scientists are devoted to the research of internal migrations and temporary relocations in Ukraine [3]. The most thorough information about the extent of migration flows in Ukraine and labor migration is provided by the modular sampling on the labor migration issue [4]. Migration determinations and factors of migration relocations can be found in the sociological researches of Ukrainian migrants [5] and in the ideas and wishes of the Ukrainian youth [6]. Offices of international organizations in Ukraine monitor the situation with the internally displaced persons (IDPs) and study their socio-economic state [7]. The problems of the sociological support of the IDPs, possible solutions and ways of need satisfaction are highlighted in the scientific works [8].

\section{Purpose and objectives of research}

The aim of the article is to study new issues connected with forced migration within the territory of Ukraine and outside its borders.

In order to achieve the determined aim, the following tasks should be fulfilled:

1. The analysis of the current internal and external migration in Ukraine.

2. The investigation of the characteristics and consequences of forced migration, caused by the annexation of Crimea and events on the East of Ukraine.

3. The analysis of issues which are faced by the IDPs and reasons which encourage Ukrainians to migrate abroad.

4. The suggestions concerning the intensification of state efforts in the sphere of migration policy in Ukraine. 


\section{Materials and method of research}

The materials of the State Statistics Service of Ukraine, the Ministry of Social Policies of Ukraine, the State Migration Service of Ukraine, the results of households' investigations and other social studies were used in this research. During the preparation of the article, general scientific principles of the systematic approach were used along with the dialectical method, the method of economic, sociological and statistical analysis.

\section{Result of the research}

The article suggests the way of minimization of the problems of internally displaced persons and offers concerning intensification of state efforts in the sphere of migration policy in Ukraine.

\section{Discussion of the result}

In Ukraine events that have social and economic consequences have lately been taking place and, therefore, a great number of forced migrants have appeared. These people have to change their place of residence because of the reasons they cannot influence, in order to save their lives and lives of their family members, avoid persecution and violation of rights and freedoms, and the consequences of the armed conflict. Such people are called internally displaced persons (IDPs) in the case if they stay in the country of their citizenship [9].

According to the State Migration Service of Ukraine, as for April 21, 2016 a total number of such people who moved from the temporarily occupied territory and areas of the antiterrorist operation to other regions is 1030.9 thousand (639.3 thousand families) [2]. According to the information of the Office of United Nations High Commissioner in Ukraine, as for August 14, 2015 there were 1438 thousand forcedly displaced people [10]. According to the UN data, the number of refugees and internally displaced people in Ukraine is much higher - 1.8 million people (including those who moved in other regions of Ukraine and those who went abroad).

It should be emphasized that the results of sociological studies show that there is a great number of young people among internally displaced people. Thus, among all questioned people, $50 \%$ is youth aged $16-35$, and $66 \%$ - women [6]. As a result, there is a great load on the labor market, especially in certain regions of the country.

According to the information of the State Emergency Service of Ukraine, as for December 31, 20151012791 people were located on the territory that is under control of Ukrainian government, including 992091 people from Donetsk and Luhansk regions and 21700 people from Autonomous Republic of Crimea and city Sevastopol. The highest number of internally displaced people is in Luhansk region (247 872), Kharkiv region (208 715), Donetsk (116 618), Dnipro region (86 666), Zaporizhia region (67 257), Kyiv region (47 599) and in Kyiv itself (39 047); the lowest number is in Ternopil region (2 727), Chernivtsi region (2 757), Rivne region (3 406), Zakarpattia region (4 056), Ivano-Frankivsk region (4 064) and Volyn region (4 501) [2].

Such flows of the forced migration caused drastic changes in directions of internal migration and its structure. According to the State Statistics Service of Ukraine, in 2015 total amount of internal migration was the least from 2010 and it was 533278 people (Table 1). This number can be the result of excluding a temporarily occupied territory of Autonomous Republic of Crimea and city Sevastopol, and a portion of Donetsk and Luhansk regions [2]. This index also became lower among young people and was 322944 people in 2014 as compared to the index of previous years (440 214 in 2010 and 403321 in 2013). The most attractive for internal migrations, as usual, are Kyiv and Kyiv region which leave behind other regions of Ukraine, such as Kharkiv and IvanoFrankivsk. The least attractive, not taking into account Donetsk and Luhansk regions, are Dnipro, Zakarpattia and Zhytomyr regions.

Among young people the surplus of internal migration stays negative. The number of people aged 15-35, who arrive, significantly exceed the number of those, who leave the Kyiv city (9396 people in 2014), Kharkiv region (2625 in 2014), Odessa region (2097 in 2014), Lviv region (1239 in 2014), Kyiv region (4340 people in 2014), Ivano-Frankivsk region (460 people in 2014) and Volyn region (256 in 2014). Donetsk and Luhansk regions suffer the largest migration losses among youth. To some extent, it is the educational migration. 
Table 1

Migration increase (decrease) of population in Ukraine in 2010-2015 (people)

\begin{tabular}{|c|c|c|c|c|c|c|c|}
\hline No & Regions & 2010 & 2011 & 2012 & 2013 & 2014 & 2015 \\
\hline 1 & AR Crimea & 1140 & 1463 & 84 & 780 & - & - \\
\hline 2 & Vinnytsia & -1029 & -337 & -1749 & -1388 & 331 & 686 \\
\hline 3 & Volyn & -109 & 475 & -613 & -1 & 695 & 119 \\
\hline 4 & Dnipro & -1075 & -1346 & -1564 & -2169 & 431 & -1351 \\
\hline 5 & Donetsk & -2130 & -2089 & -4449 & -4516 & -10677 & -9239 \\
\hline 6 & Zhytomyr & -613 & -714 & 426 & -1254 & -476 & -1280 \\
\hline 7 & Zakarpattia & -772 & -393 & -370 & -905 & -849 & -1651 \\
\hline 8 & Zaporizhia & -529 & -1387 & -1361 & -1916 & -847 & -797 \\
\hline 9 & Ivano-Frankivsk & 87 & 254 & -40 & 183 & 1241 & 1901 \\
\hline 10 & Kyiv & 3990 & 7476 & 7072 & 8821 & 11120 & 11225 \\
\hline 11 & Kropivnitsky & -1023 & -1585 & -2160 & -2183 & -846 & -688 \\
\hline 12 & Luhansk & -2621 & -3061 & -4034 & -4365 & -8120 & -5634 \\
\hline 13 & Lviv & -818 & -1590 & -794 & -775 & 1543 & 1335 \\
\hline 14 & Mykolaiv & -738 & -961 & -1659 & -1379 & 644 & 206 \\
\hline 15 & Odessa & 2180 & 1523 & 2782 & 2533 & 4639 & 986 \\
\hline 16 & Poltava & -370 & -754 & -1203 & -554 & 1050 & 990 \\
\hline 17 & Rivne & -098 & -1774 & -1491 & -1151 & -155 & -782 \\
\hline 18 & Sumy & -145 & -1126 & -1423 & -1602 & -401 & -974 \\
\hline 19 & Ternopil & -071 & -844 & v565 & -1233 & 72 & 250 \\
\hline 20 & Kharkiv & 222 & 366 & 1984 & 1741 & 8261 & 4981 \\
\hline 21 & Kherson & -374 & -1301 & -2157 & -2145 & -858 & -301 \\
\hline 22 & Khmelnytskyi & -811 & -1554 & -1006 & -1171 & 27 & -174 \\
\hline 23 & Cherkasy & -775 & -157 & -1202 & -1242 & 308 & -188 \\
\hline 24 & Chernivtsi & 272 & 512 & 316 & 681 & 1397 & 996 \\
\hline 25 & Chernihiv & -348 & -191 & -1321 & -1432 & -381 & 155 \\
\hline 26 & city Kyiv & 8366 & 8163 & 14703 & 14222 & 14443 & 13462 \\
\hline 27 & city Sevastopol & 1192 & 932 & 1794 & 2420 & - & - \\
\hline & Total in Ukraine & 652639 & 637713 & 649865 & 621842 & $542506^{*}$ & $533278^{*}$ \\
\hline
\end{tabular}

Source: According to the data of the State Statistics Service of Ukraine. * - data are given excluding a temporarily occupied territory of Autonomous Republic of Crimea and city Sevastopol, and the area of antiterrorist operation on a portion of Donetsk and Luhansk regions

Internal migration in Ukraine mostly takes place in a format "village-town" because of better socioeconomic conditions in urban areas. The number of rural population has been decreasing annually by $0.1 \%$ (or $80-90$ thousand) in favor of urban population: in 2015 rural population was $30.9 \%$ as compared to total number of population, and in $2014-31.0 \%$ [2].

As to internally displaced people, they experience low level of well-being, job and housing security. According to the results of studies of IDPs in Ukraine, conducted by the International Migration Organization in cooperation with Ukrainian Social Reform Centre and sponsored by the European Union, only $41 \%$ of households have employment income. Moreover, $28 \%$ of people who were employed earlier managed to find a job in a new place of residence and only $4.5 \%$ of those who did not work before. $42 \%$ of internally displaced people have to economize on food, $37 \%$ of people can afford only food, $19 \%$ of respondents can satisfy their urgent needs, and only $0.7 \%$ of them have savings. A significant amount of respondents rent their dwelling (68 \%): $42 \%$ of people rent a flat, $20 \%$ - a house, and $6 \%$ rent a room in a flat. $22 \%$ of respondents live at their relatives or host families, $7 \%$ - in dorms or shared residence centers [7]. 
Problems with employment, low level of well-being, lack of their own dwelling and high level of rent encourage a part of forced migrants to go abroad. Thus, according to the data of the Office of United Nations High Commissioner in Ukraine, as for August 14, 2015, the number of Ukrainian citizens who applied with a request for asylum in neighboring countries was 388.8 thousand people, besides, 732.0 thousand people stayed in these countries under other reasons, including the following: in Russian Federation 383.3 thousand people looked for asylum and 528.2 thousand lived under other reasons; in Belarus - 1200 and 125.2 thousand people respectively; in Poland - 3.9 and 64.3 thousand respectively [10].

It should be mentioned that official statistical data do not show real extent of migration, because some citizens leave the area of military actions by themselves without registration (move to relatives, familiars etc.). Furthermore, it is impossible to make accurate estimations during military actions and antiterrorist operation.

External migration of Ukrainian population has undergone significant changes. In particular, migration flows to Russian Federation are reducing as a result of tense relations with this country and implementation of stricter regulation norms of labor immigration. For instance, in 20126104.4 thousand people visited Russia, and in 2015 the number of Ukrainian citizens who visited Russian Federation decreased to 4161.1 thousand. In recent years, the most visited country by Ukrainians is Poland: in 20137018.2 thousand and in 20159519.2 thousand people went there, though in 2010-2012 Russian Federation was a leader of migration trips. In 2015, the most visited countries also were Romania (4 161.1 thousand) and Hungary (2 442.2 thousand), and as for Belarus and Moldova, they lost their points - 1390.8 thousand and 1731.6 thousand accordingly [2]. It should also be mentioned that starting from 2014 Ukrainian citizens started to prefer countries-members of the EU to countries of former USSR.

In 2015, one could observe a surplus of international migration, and starting from 2012 the number of immigrants increased as compared to the number of emigrants. Almost in all regions of Ukraine one can observe migration increase of population with the exception of Zakarpattia ( -1253 people), Dnipro ( -174 people) and Rivne ( -14 people) regions [1] which lose the number of their citizens because of internal migration.

The major reason for Ukrainians to migrate is economic one. Thus, the results of sociological studies "Youth of Ukraine - 2015" show that the majority of young people who intend to emigrate point out that they can earn money or improve their living conditions (64\%), and that there are much more employment opportunities abroad (56\%). Military actions and security problems in Ukraine encourage $49 \%$ of migration orientated young people to go abroad. Almost a half of young people $(46 \%)$ have pointed out that their reason for emigration is absence of democracy and justice in Ukraine [6].

Official statistical data do not give accurate number of people who work abroad. In 2015, 76.9 thousand of Ukrainian citizens worked on the territory of foreign countries in companies that had appropriate licenses (in 2013 - 83.4 thousand people) [1].

The results of sampling inquiries can show more or less real flows of labor force abroad. Thus, starting from 01.01.2010 till 17.06.2012 the number of Ukrainian citizens aged 15-70, who worked or looked for a job abroad, was estimated as 1.2 million people or $3.4 \%$ of active working age population. $51 \%$ of labor migrants (602.5 thousand people) worked or looked for a job in the EU, $43.2 \%$ (511.0 thousand) - in Russia. In addition, labor migration is more common among male respondents. Moreover, the majority of labor migrants are rural residents (54.3\% of a total number of labor migrants) and individuals aged $25-49$, and the average age of migrants is 37 [4].

Other results of the sociological study show that in 2015 the number of extended families, the members of which were working abroad at the time when the study was conducted was $5.4 \%$ (or 515.9 thousand people), in $2011-5.5 \%$ (or 504.0 thousand people). The increase in the number of migrants who work unofficially is quite disturbing: in 2015 their number was $40.5 \%$ of respondents (app. 208.7 thousand people), whereas in 2011 - $27.6 \%$ (139.5 thousand people), in $2008-20.6 \%$ (154.0 thousand), and in 2006 - 30.1\% (328.2 thousand people) [5]. 
Ukraine is not only a source of labor migrants for countries of the EU, but also a transit country for illegal migration flows. In 2015, a total number of illegal migrants detained by border police increased by $30 \%$ (in 2014 - 2723 individuals; in 2015 - 3536 individuals). Moreover, the number of detained for illegal border crossing almost doubled (in 2014 - 960 individuals; in 2015 - 1804 individuals). The number of illegal migrants detained for illegal border crossing increased on Ukrainian-Hungarian and Ukrainian-Romanian parts of the state border. On other parts of the Ukrainian state border their number is mostly the same [2].

The structure of illegal migration, taking into account citizenship of migrants, did not change a lot, but it became more active. Thus, in 2015 quantitative characteristics of illegal migration increased due to citizens of Afghanistan (2015 - 667 individuals, 2014 - 228 individuals), Syria (2015 - 190, 2014 - 140), Georgia (2015 - 111, 2014 - 66), Somalia (2015 - 83, 2014 - 23), Sri Lanka (2015 - 60, 2014 - 28), and Vietnam (2015 - 48, 2014 - 42). The number of Moldavian citizens a little bit decreased (in 2015 - 139, 2014 - 181) [2].

In our opinion, quite a significant channel of illegal border crossing was a Ukrainian-Russian part of the state border adjacent to Donetsk and Luhansk regions. On the one hand, with the beginning of the conflict on the East of Ukraine this channel became partly unavailable, but, on the other hand, today illegal flows of migrants through a temporarily occupied territory and areas of antiterrorist operation could significantly increase. But because of the absence of official data of the Border Guard Service this hypothesis cannot be proved.

To sum up, illegal migration from Ukraine and through its territory can be much more intensive. Among major factors there are the following ones: high transit potential, close geographical position to countries of the EU and the activity of citizens from countries of Southeast Asia, Middle East and Africa in obtaining Ukrainian visas.

\section{Conclusions and recommendations}

The conducted analysis of the current internal and external migration in Ukraine showed significant changes of the migration flows directions. Today Ukrainians, going abroad, are focusing more on European countries, while the number of visitors to countries of Commonwealth of Independent States, especially Russian Federation, who go there in order to get employed, is gradually reducing. The number of Ukrainian labor migrants who work unofficially continues to increase. As a result, their rights and freedoms are often violated.

The investigation of the characteristics and consequences of forced migration, caused by the annexation of Crimea and events on the East of Ukraine, allowed finding the most attractive for the migrants regions of Ukraine (Kharkiv region, Dnipro region, Zaporizhia region, Kyiv region and in Kyiv itself).

There were also singled out the issues faced by the IDPs: low level of well-being, job and housing security. The analysis of the sociological researches allowed discovering reasons which encourage Ukrainians to migrate abroad. Among them are state inability to provide its citizens with normal living and proper socio-economic conditions, decent salary and opportunities of better employment. Military actions on the East of the country have also greatly influenced the overall situation.

The result of this research is proposals for minimizing the above problems and enhancing the efforts of the state in the sphere of migration policy of Ukraine. The government should calm emigration moods among Ukrainian population and internally displaced people in particular; foster social security of Ukrainian workers abroad. To establish conditions for returning of Ukrainian migrants to their Motherland; to intensify the cooperation with recipient countries on employment assistance. To create new working positions on the territory which is under control of Ukraine and in areas, where the most of internally displaced people live (e. g., implementation of privileges for employers and quotas in government agencies). To conduct information campaigns among internally displaced on the issues of self-actualization, employment, adaptation to new living conditions, overcoming disturbing psychological states. To foster the development of small-scale and middle-scale businesses among IDPs and the whole population of Ukraine. To develop a constant monitoring system in order to coordinate 
all governmental levels and solve the problems of IDPs more effectively. To continue the development of a regulatory framework concerning the settlement of IDPs' problems taking into consideration the UNO leading principles regarding internally displaced people.

\section{References}

[1] Mihratsijnyj rukh naselennia u 2015 rotsi (2015). Derzhavna sluzhba statystyky Ukrany Available at: http://www.ukrstat.gov.ua

[2] Mihratsijnyj profil' Ukrainy: 2011-2015 (2016). Available at: http://dmsu.gov.ua/images/files/ MP2015.pdf

[3] Malynovs'ka, O. A. Vnutrishnia mihratsiia ta tymchasovi peremischennia v Ukraini v umovakh politychnykh ta sotsial'no-ekonomichnykh zahroz. Available at: http://www.niss.gov.ua/content/articles/files/ vnutrishnya_migratsia-45aal.pdf

[4] Zvit schodo metodolohii, orhanizatsii provedennia ta rezul'tativ modul'noho vybirkovoho obstezhennia z pytan' trudovoi mihratsii v Ukraini. (2013). Mizhnarodna orhanizatsiia pratsi. Budapesht, MOP.

[5] Doslidzhennia z pytan' mihratsii ta torhivli liud'my: Ukraina, 2015 r. GfK Ukraine Available at: http://www.iom.org.ua/sites/default/files/pres_kit_gfk_iom2015_ua_fin_3_2.pdf

[6] Sotsiolohichne doslidzhennia «Prahnennia, bachennia rozvytku i pohliady ukrains'koi molodi». GfK Ukraine. Available at: www.britishcouncil.org.ua

[7] Natsional'na systema monitorynhu sytuatsii z vnutrishn'o peremischenymy osobamy. Raund 2, Kviten' 2016 (2016). Ukraina. Predstavnytstva v Ukraini Mizhnarodnoi orhanizatsii z mihratsii. Available at: http://www.iom.org.ua/sites/default/files/iom_nms_r1_ukr.pdf

[8] Malynovs'ka, O. A. Shliakhy vyrishennia problemy vnutrishnikh peremischenykh osib: deiaki uroky iz zarubizhnoho dosvidu. Available at: http://www.niss.gov.ua/articles/1609/

[9] Zakon Ukrainy «Pro zabezpechennia prav i svobod vnutrishn'o peremischenykh osib». Available at: http://zakon0.rada.gov.ua/laws/show/1706-18/page1

[10] Upravlinnia Verkhovnoho komisara OON u spravakh bizhentsiv (2015). Available at: http:// unhcr.org.ua/en/2011-08-26-06-58-56/news-archive/1244-internal-displacement-map 